\title{
Values within reason
}

Andrew Sayer, Lancaster University, UK, June 2017

Draft of paper published in 2017 in Canadian Review of Sociology, 54 (4) pp.468-475

When a doctor takes our blood pressure and gives us those two numbers, one over the other, then unless we've read up on the topic, we may have to ask 'is that good or bad?' We don't expect the doctor to reply, 'I can't tell you because that would be a value-judgement, and it would compromise the objectivity of the test'. And if we ask, 'ought I to do anything about it?' we don't expect the doctor to say 'sorry, but you can't deduce ought from is'. Such replies would make us wonder about the sanity of the doctor, indeed whether they could claim to be a doctor at all. ${ }^{1}$ When we are discussing health we are dealing with something that is inescapably normative, that is, evaluative, at the same time as it concerns matters of fact, so that values and objectivity appear not to be incompatible. Is the situation of social science so different from the medical one?

The ideas that facts and values are radically different and should be kept apart, and that factual statements don't entail ought statements, have proved to be remarkably resilient in social science, even though many respected philosophers don't support them (Anderson, 2004; Appiah, 2008; Bhaskar, 1979; Collier, 2003, Geuss, 2008; MacIntyre, 1981, 1998; Putnam, 2002; Taylor, 1967, 1994; Williams, 1985). For many social scientists, values and objectivity don't mix: we need to resist value-judgements in order to be objective. As Max Weber said: "Whenever the person of science introduces his personal value judgment, a full understanding of the facts ceases" (Weber, 1946, p.146). Of course there are plenty of social scientists who don't believe that social research can be valuefree, but they usually assume this means it can't be objective. Many times I've heard social scientists say 'Like anyone, I have my particular value standpoint, so I can't pretend to be objective.' So here we see that both sides - conservatives and radicals - actually agree on the same crucial point: that values and objectivity are incompatible. Indeed, for both, to be objective is precisely to be value-free.

I wish to argue that this shared assumption is mistaken, that evaluation is necessary for objective description in social science, and that the popular framing of the issue of values as a matter of whether 'ought' follows from 'is' misrepresents normativity. I shall further challenge the treatment of values as arational and merely subjective and go on to argue that these problems reinforce alienated views of human actors that fail to understand the normative character of life.

Both the conservatives and the radicals are captives of a radically dichotomous and incompatiblist view of the relation between facts and values. If we compare the writings of the founders of social science in the $18^{\text {th }}$ and early $19^{\text {th }}$ century with contemporary social research, the former are strikingly judgemental or evaluative about the practices they seek to explain. In Adam Smith's work, for example, we find numerous evaluations woven into the analyses of the practices

1 This, incidentally, shows how the very definition of social roles involves normative criteria. 
of the emerging commercial society, and plenty of references to greed, vanity, avarice, benevolence, and so on (Smith, 1859; 1876). In other words, there is no segregation of positive (descriptive/ explanatory) from normative (evaluative) content. In the latter part of the $19^{\text {th }}$ century, however, many social scientists sought to expel value-judgements from their accounts, so that, for example, mainstream economists came to use neutral, indifferent terms like 'interest' and 'utility' rather than greed or vanity. What is less often noticed is that the flip side of this attempted expulsion of values from social scientific reason was an attempted expulsion of reason from values (Bhaskar, 1998). This allows values to be dismissed as not answering to rational argument, and as 'merely subjective', rather than about something (O'Neill, 1998, pp.43ff; Sayer, 2011). From there it is but a short step to thinking of them as irrational, and as a contaminant in scientific reasoning. Weber's comically neurotic association of values with 'demons' and 'demagogues' is an extreme case of this de-rationalisation of values. Yet most of us have changed some of our values at some point in our lives and can give reasons for doing so; for example, the reformed racist is likely to point to their realisation that there are errors of fact and reasoning in racist beliefs about the implications of physical and cultural differences among people. Actually, Weber's advice to teachers to present their students with facts that are 'inconvenient' in relation to their values is in contradiction with his general treatment of values as incompatible with science because it is only if valuejudgements are susceptible to empirical evidence that any facts can be inconvenient.

While opponents of the value-freedom principle believe that values cannot be excluded from social scientific accounts they often fail to challenge the derationalisation of values, and this, in turn, tends to make them conclude that social science can't be objective. The problem here is that both advocates and opponents of value-freedom tend to slide between different meanings of 'objective' without noticing. As we have noted, one sense of 'objective' defines it in terms of value-freedom. But this is often confused with another quite different epistemological sense of 'objective', concerning the truth status of statements. The claims social scientists make about the world may be more or less true (objective), in this sense. ${ }^{2}$ Immediately, it should be clear that value-free statements are not necessarily objective in the sense of true; all statements including straightforwardly factual claims, such as 'water boils at x C' - are fallible. But a value-laden statement such as 'millions of people are suffering in Syria' could be true or false as a claim about what is happening. That the use of the term 'suffering' involves a 'value judgement' about a state of affairs does not necessarily make it wrong. Its use is not reducible to a gratuitous subjective judgement arbitrarily projected onto others by an observer: rather it is a fallible description of a state of being. And if you don't know that suffering or failing to flourish are bad, you don't know what they are.

In social science we study living, sentient beings who are capable of suffering or flourishing. As Mary Midgley says "You cannot have a plant or an animal without

\footnotetext{
2 There are other senses of 'objective' too. One is ontological, referring to states or events themselves, regardless of whether or how we think of them.
} 
certain quite definite things being good and bad for it." (Midgley, 2003, p.54.

When a doctor says a child is 'failing to flourish', this is an evaluative description, and one which may be true. An account of that child which gave no indication that it was failing to flourish would be deficient as a description. In such cases it is clear that evaluative judgements of good or bad are necessary if we are to describe people adequately. So while, we may still sometimes want to distinguish between evaluative and value-free or non-evaluative claims, I suggest that we stop describing the latter as 'objective', as it typically encourages confusion with 'objective' in the sense of 'true'. When we are talking about living beings, which must have things that are good or bad for them, the fact-value dichotomy breaks down.

This argument conflicts with the common assumption that the positive and normative content of discourses must be inversely related, as Weber thought. Consider the following famous example, comparing two statements about the Holocaust: 'thousands died in the Nazi concentration camps' and 'thousands were systematically exterminated in the Nazi concentration camps'. ${ }^{3}$ The second is both more value-laden and more factually accurate than the first: the prisoners did not just die naturally, nor were they killed randomly and individually, but in planned mass executions. Therefore, refraining from using evaluative terms may weaken rather than strengthen the descriptive adequacy or truth status of our accounts.

Although terms like 'flourishing' or 'suffering' are vague, covering wide ranges of conditions, they seem to be both descriptive and evaluative. If we reflect on more specific adjectives like 'oppressive', 'humiliating', 'abusive', 'cruel', 'kind', 'compassionate', or 'generous', which involve what philosophers term 'thick ethical concepts', we can see more clearly that they are both descriptive and evaluative, and one cannot separate the two components from one another (Putnam, 2002, p.35ff; Taylor, 1967, 1994; Williams, 1985). ${ }^{4}$ Thus, when we decide to accept a description of some practice, say, as 'oppressive' or 'racist', we simultaneously accept the implicit valuation.

By comparison, thin ethical concepts such as 'good',' bad', 'duty', 'virtue', 'obligation', 'right' and 'wrong' - "empty moral words", as Iris Murdoch called them - can seem more like arbitrary assertions than reasonable descriptions and evaluations (Murdoch, 1970, p. 40). This is precisely because as abstractions and summarising terms, they are removed from the range of concrete situations and behaviours to which they might be applied and in terms of which they can be justified (Putnam, 2002, p.60). They are noun-dependent: that is, they lack meaning until they are attached to a noun, as in 'good student' or 'bad teacher'. No wonder that, left unattached, they should appear to be beyond the scope of reason (MacIntyre, 1981).

\footnotetext{
${ }^{3}$ For a fuller discussion, see Taylor, 1967.

4 "For an Aristotelian, the sharp division between factual and evaluative claims makes no sense." (Taylor, 1994, p.20)
} 
Believers in value-freedom may feel that they should replace such terms with less evaluative ones, but if they do, one of two things will happen: either they will mislead by euphemising, as in the use of the term 'collateral damage' for the killing of non-combatants in war, in which case the account will be deficient descriptively as well as evaluatively, or else the new words will come to take on a similar evaluative load to the ones they replaced.

A standard move of proponents of value-freedom is to invoke the nondeducibility of ought statements from factual statements: 'no ought from is'. This pithy point is often assumed to settle things, and on its own terms it seems unassailable, yet it is a strange and loaded way of addressing the issue of valuefreedom for it immediately reduces values and normativity to imperatives and ignores thick ethical concepts. However, value-judgements are primarily evaluations rather than imperatives. They don't fall neatly into one or other side of the fact-value or is-ought binaries, but lie between them. The is-ought binary renders them invisible, and is therefore a thoroughly misleading way of framing the issue of values in social research. Secondly, even radical social scientists rarely say in their research what they think ought to happen, but they do often evaluate practices: for example, as racist or exploitative..$^{5}$ Thirdly, it's peculiar to assume that the only inferences worth considering are logically deductive ones. Rather little of scientific reasoning involves deduction: induction, retroduction (inferring the presence of possible causal mechanisms) and argument by analogy are more common (Bhaskar, 1975; Taylor, 1967). Fourthly, it confuses the things of logic with the logic of things. The no-is-from-ought argument is about logic, which concerns the relations between statements, but values are often about states of being. If someone is starving, they don't need a logical argument for getting some food. They just need food. The force of the 'ought' here is not a matter of the logical relations between statements, but of bodily needs or compulsions - states of being or becoming, not statements.

As Charles Taylor argues, values are implied not only in thick ethical terms but in the way in which issues are framed, that is, how particular social phenomena of interest are contextualised. The frames are simultaneously descriptive and value-laden insofar as they imply a certain general view about human needs and nature and about what enables people to flourish or suffer (Taylor, 1967). Though particular terms, phrases or sentences may be largely value-free when taken in isolation (e.g. 'Catholics tend to vote Democrat'), the frames implied by the larger discourses of which they are part create what he calls a 'value-slope', which tends to 'secrete' certain values and encourage the reader or listener to

\footnotetext{
5 The derationalized view of normativity constructed by the is-ought framework is not limited to positivists, but is found in post-structuralism. Michel Foucault, when asked why he tried to avoid all evaluative judgements in his work, reproduced the same error when he said that "the role of the intellectual is not to tell others what they have to do." Foucault (1997a, p.131) His aversion to evaluative description means that his work is therefore not only crypto-normative, as Habermas (1990) claimed, but crypto-descriptive. Post-structuralism also tends to reduce normativity to 'normalising judgements', seeing these as suppressing difference, and therefore dangerous. While they can be repressive, it is disastrous to try to treat normativity as problematic, and of course it's contradictory, for to condemn it is to make a normative judgement.
} 
evaluate the phenomena being described in a certain way. They do not logically entail a particular conclusion, but rather suggest one through what they imply about human well-being. Thus an account of capitalism which centres on consumers choosing what to buy is likely to create a positive response in that it highlights individual liberty and autonomy, while one which centres on unemployment is likely to secrete more critical responses because it suggests failure to satisfy people's need for security. Listeners are of course free to disagree with the secreted values, though if they do they might be expected to justify their response. Two options are then open to them. They can respond by attempting to undermine the account, for example, denying that capitalism tends to produce job insecurity or that unemployment causes any harm. Alternatively they can adopt an overriding strategy that concedes that the secreted values have some warrant, but argues that other concerns override them; for example, they might argue that while economic insecurity is a problem, it is a lesser evil than possible alternatives, such as guaranteed employment, which might inhibit economic development and freedom to change job.

While these arguments focus on whether ought might follow from is, what tends to worry social scientists most about values, is the converse one of how their values might influence their accounts, in particular, the fear that evaluative judgements will distort understanding of what is the case. Social scientists may decide not to engage with the undermining or overriding arguments that might be prompted by their research, but they cannot avoid the issue of choosing appropriate framings of their topics. To be sure, they shouldn't just choose whatever framing fits with their current values but choose the frame that explains the subject most adequately, yet they can't avoid implying some evaluative judgements about what is good or bad for people. As Elizabeth Anderson's discussion of research on divorce shows, values can illuminate as well as obscure, prompting hitherto unnoticed facts to be revealed (Anderson, 2004). Researchers who viewed divorce as a social problem tended to frame their research accordingly, and overlooked certain benefits that people going through the process experienced. Researchers whose values regarding divorce were more mixed and saw it as having possible benefits as well as costs asked questions that revealed these. Further, remembering that reasoning about values is susceptible to evidence - because values are about something independent of the valuer, someone with a wholly negative view of divorce might have their views changed by reading such research. Far from being a contaminant threatening the objectivity of social research, values may help achieve adequate understanding. As Anderson concludes, what we should worry about is not values as such, but dogmatically-held values. And it is precisely the irrationalist view held by Weber of values as demagogues and demons that supports dogmatic attachment to values.

Finally, the attempted de-rationalisation and expulsion of values from social science has tended to sustain partial and often alienated views of its own object, social life itself. Subjectivist and conventionalist theories of value common in social science, that treat values as either merely subjective projections of observers onto situations or as mere conventions ('what folks do round here'), fail to understand normativity and its import in everyday life. If someone is 
harming us, we don't say 'please stop, as subjectively I happen not to like it' or 'please stop: don't you know that's not what folks do round here?' We tell them to stop because it is harming us, causing us to suffer. This eudaimonistic concept of value, in which values are tied to our capacities for flourishing and suffering, is inescapable. As beings who are capable, vulnerable, and needy, and as social beings dependent on others, we are continually monitoring and evaluating our situation and what we should do, whether it be of minor importance (what shall I have for dinner?) or major ('should I quit this job, end this relationship?'). Life is normative: we are always moving between various mixes of suffering and flourishing, between things as they are, and as they might be, for better or worse, between states of lack, desire, yearning and possible states of fulfilment. Further, people develop concerns, attachments and commitments, and their well-being depends significantly upon how these are faring (Archer, 2000). Thus, for example, important though Bourdieu's concept of habitus is for appreciating the importance of embodied dispositions in determining how people act, their relation to the world is not just one of neutral adaptation to dominant relations and practices that they encounter, but of conscious or semi-conscious evaluative monitoring of their feelings and concerns, as beings who can flourish and suffer, and notice and care about the difference. Of course, people can mistake what might enable them to flourish, but that's precisely because their values are about something that isn't reducible to subjective projection, construction or wishful thinking. Mistaken beliefs imply the existence of something different from beliefs about which they can be mistaken. Our relation to the world is one concern. As social scientists trying to describe and explain this world, we have to report how those whom we study see things, but if we fail to point out where they misidentify them, as in the case of say, a racist making deluded judgements about the nature of Muslims, our descriptions and explanations will be deficient.

Wittgenstein was probably thinking of natural science when he said "We feel that even when all possible scientific questions have been answered, the problems of life remain completely untouched." (Wittgenstein, 1922, 6.52), but in social science, we can begin to understand them if we engage with social beings as both capable and vulnerable and as having a relation to the world of concern.

For all these reasons, the doctrine of axiological neutrality is based on an alienated and alienating view of values in science and everyday life, and it obstructs our understanding of both.

\section{References}

Anderson, E. 2004, 'Uses of value judgements in science: a general argument,with lessons for a case study of feminist research on divorce' Hypatia, 19 (1), pp.1-24 Appiah, K.A. 2008, Experiments in Ethics, Cambridge MA: Harvard University Press

Bhaskar, R. 1975, A Realist Theory of Science, Leeds: Leeds Books, 2nd edn 1979, Brighton: Harvester

Bhaskar, R. 1998, The Possibility of Naturalism, London: Routledge

Collier, A. 2003, In Defence of Objectivity, London: Routledge 
Foucault, M. 1997, 'What is critique?' in Lotringer, S and Hochroth, L. (eds.) The Politics of Truth, NY: Semiotexte.

Geuss, R. 2008, Philosophy and Real Politics, Princeton, NJ: Princeton University Press

Habermas, J. 1990, Moral Consciousness and Communication Interaction, Cambridge: Polity

MacIntyre, A. 1981, After Virtue: A Study in Moral Theory, London: Duckworth MacIntyre, A. 1998, A Short History of Ethics, London: Routledge

Midgley, M. 2003, rev'd edn., Heart and Mind, London: Routledge

Murdoch, I. 1970, The Sovereignty of Good, London: Routledge

O'Neill, J. 1998, The Market: Ethics, Knowledge and Politics, London: Routledge

Putnam, H. 2002, The Collapse of the Fact-Value Dichotomy, Cambridge, MA:

Harvard University Press

Sayer, A. 2011, Why Things Matter to People, Cambridge: Cambridge University

Press

Smith, A. 1759:1984, The Theory of Moral Sentiments, Indianapolis: Liberty Fund Smith, A. 1776:1976, An Inquiry into the Nature and Causes of the Wealth of Nations $_{\mathbf{2}}$ ed. by E.Cannan, Chicago: University of Chicago Press

Taylor, C. 1967. 'Neutrality and political science'. In: Alan Ryan (ed.) 1973 The

Philosophy of Social Explanation, Oxford: Oxford University Press, 139-170.

Taylor, C. 1994, 'Justice after virtue', in Horton, J. and Mendus, S. (eds) After

MacIntyre, Polity Press, pp. 16-43

Weber, M. 1946, Max Weber's Science as a Vocation, ed. P. Lassman and I.Velody with H. Martins, London: Unwin Hyman

Williams, B. 1985, Ethics and the Limits of Philosophy, Oxford: Oxford University Press

Wittgenstein, L. 1922: 2001, Tractatus Logico-Philosophicus, London: Routledge 